\title{
Windows Influence on Room Daylighting in Residential Buildings
}

\author{
Haşim Altan ${ }^{1}$ and Jitka Mohelnikova ${ }^{2}$ \\ 1. Faculty of Engineering \& IT, The British University in Dubai, Dubai 345015, United Arab Emirates \\ 2.Faculty of Civil Engineering, Brno University of Technology, Brno 602 00, Czech Republic
}

\begin{abstract}
Daylighting studies in buildings are key parts of environmental analysis and can be easily conducted at the early stages of design as part of environmentally responsive building design as well as to inform the final architectural layout and interior design. The main aim of this study is to demonstrate how such daylighting studies can be completed at the early stages of design and, at the same time, to show the impact of window design and positioning on building indoor environments. The paper is focused on a study of window influence on room daylighting in residential buildings and computer lighting simulations in software packages: Windows Daylighting System and Autodesk Ecotect Analysis, have been carried out for different style and positioning of windows using several case studies. The main findings clearly indicated that not only the window size and style matters, but also the positioning of windows considering external walls which would make a significant influence on room daylighting levels and, therefore, such daylight studies are very important for the early stage of environmental analysis during building design.
\end{abstract}

Key words: Lighting analysis, daylight studies, computer simulations, daylighting levels, window size and positioning, residential buildings.

\section{Introduction}

Daylighting in buildings plays a key role in indoor environment. The building design with respect of indoor visual comfort requires study of daylighting in the early architectural concept.

Proper indoor natural illumination is influenced by many design aspects including glazed parts of building envelopes as well as interior surfaces and their colours [1-3].

Window design depends on optimisation of glazed area for visual comfort without glare. Position of windows also plays a vital role for indoor daylighting levels and distribution [4-6].

Some studies of windows related to daylighting were published [7]. These studies are examples used for the room daylighting evaluations. In this study, the main focus is on analysis of window type and position

Corresponding author: Haşim Altan, Ph.D., associate professor, research field: sustainable design of the built environment. E-mail: hasim.altan@buid.ac.ae. in a common room. The analyses were used for window optimisation in a designed residential building.

\section{Materials and Methods}

Natural light illuminance and uniformity represent two key factors that are important for indoor visual comfort and environment. The evaluation of window's position and influence on room daylighting were studied.

Daylighting in newly designed buildings can be studied and optimised using computer simulation techniques. DF (daylight factor) is a percentage ratio between indoor illuminance on a working plane and external horizontal illuminance during overcast sky conditions [1, 3]. In the study, calculations were completed within the Astra MS Software tool called WDLS (Windows Daylighting System) [8]. This tool is used for window daylight optimisation in building zones. Although the software programme is not very comprehensive and sophisticated like the advanced simulation tools [9-11], it is convenient for common 
building design practice due to its simplicity and short calculation time.

The computer simulations were run for conditions of the CIE (International Commission on Illumination) overcast sky model [1] and the dark ground surroundings without any shading considering external obstructions. The room surfaces' reflectance values are: the floor $=0.3$, walls $=0.5$, and the ceiling soffit $=0.7$. Windows are double glazed units with clear glass panes and the light transmittance is 0.81 .

The DF (\%) distribution in control points on the working plane is $0.85 \mathrm{~m}$ above the floor level and is graphically presented in Figs. 1-5. The control points are distributed within distances $1 \mathrm{~m}$ and $0.5 \mathrm{~m}$ round of the room perimeter. Dimensions of rooms and windows were selected to be similar with a common residential building room design solution.

A narrow room of floor dimension of $3 \mathrm{~m} \times 6 \mathrm{~m}$ and clearance height $2.9 \mathrm{~m}$ was studied to be daylit by a tall vertical window (Fig. 1a) compared to the wide one of the same glazed area (Fig. 1b).

Three different positionings of window sills in the common room of dimensions $4 \mathrm{~m} \times 5 \mathrm{~m}$ and clearance height $2.7 \mathrm{~m}$ are presented in Fig. 2. Influences of the two windows' locations in perpendicular and parallel walls of a big square shape room with a floor area of 6 $\mathrm{m} \times 6 \mathrm{~m}$ and clearance height of $2.7 \mathrm{~m}$ are compared in Fig. 3.

Daylighting by an ordinary window and a French style window in the common room $4 \mathrm{~m} \times 5 \mathrm{~m}$ is presented in Fig. 4 and a comparison of a squared vertical window and roof light daylighting in room $4 \mathrm{~m} \times 4 \mathrm{~m}$ is presented in Fig. 5 .

Minimum DF $\left(D F_{\min }\right)$, maximum $\mathrm{DF}\left(D F_{\max }\right)$ and average DF $\left(D F_{\text {aver }}\right)$ are the values of daylight factor and daylight uniformity calculated as $u=D F_{\min } / D F_{\max }$, which were also compared with the particular simulation tasks.

The software WDLS daylight simulation accuracy was controlled due to comparison of the calculated results with Ecotect simulations (Figs. 6 and 7).
Figures present comparative segments of the studied rooms from Fig. 1 in variation with Window 1 (Fig. 6) and in alternative with Window 2 (Fig. 7). Despite of different graphics, the simulations give similar results of DF (\%) distribution. The Ecotect simulations give higher values compared with the WDLS software outputs as shown in Table 1.

\section{Results and Discussions}

Higher windows considering a common room space with very high sills transmit daylight deeper into the spaces of rooms (Fig. 1a) within a residential building. On the other hand, wider windows considering a standard room space give more uniform daylighting in the room area close to the window, which can be useful, for example, for study desks located near window positioning (Fig. 1b).

Windows with very high sills are recommended for illumination of the upper and distant parts of rooms, as demonstrated in Fig. 2. However, they do not allow view to exterior in rooms with occupants performing sedentary work. View to sky is not considered to be adequate for visual contact with the exterior.

Windows located in two parallel walls, as shown in Fig. 3a, can be more efficient for the room daylight uniformity compared to the same room daylighting by the two windows in perpendicular walls as shown in Fig. 3b.

The solution with two perpendicular windows can be useful for spaces with two different zones of visual activities - one zone close to windows with high daylighting levels and the second one for auxiliary space. However, in case of a small room and large windows located in two parallel walls, the glare effect can appear because of both very high intensity and window orientation.

French style windows without sills give intensive daylight on floor levels close to the glazed areas. However, window sill creates shadows at the same space and area with maximum illuminance also distributed deeper into the room space (Fig. 4). 
Internally, reflected component of DF is higher in case of the French style windows. Glazing at the position of the window sill increases solar gains in summer seasons. This fact needs to be considered also in fully glazed parapets.

Sky lights serve more daylight compared to the side light of the same dimensions (Fig. 5). High intensity of daylight can cause glare in some cases as well as it is not possible to view from the sky light. Therefore, it is recommended to combine both the side windows and sky lights for more uniform daylight distribution in large rooms.

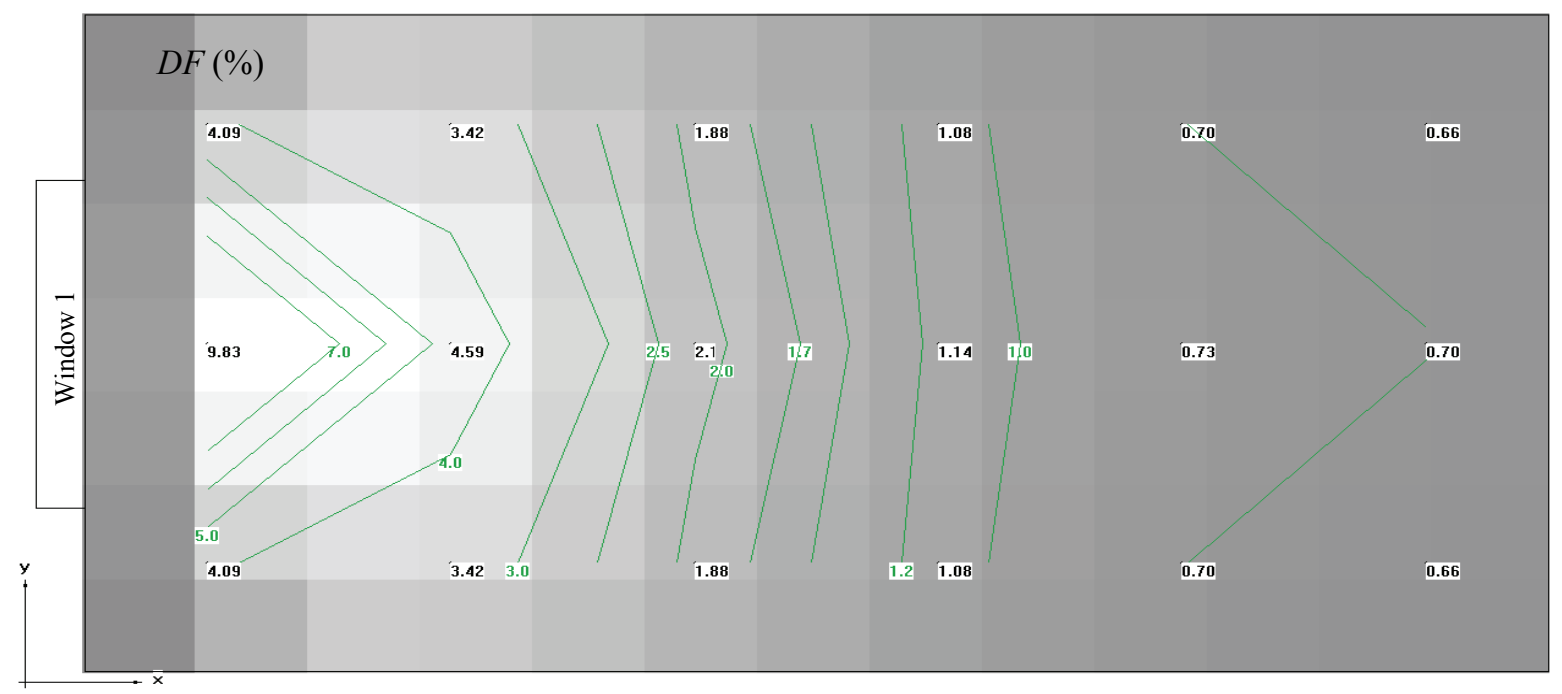

(a)

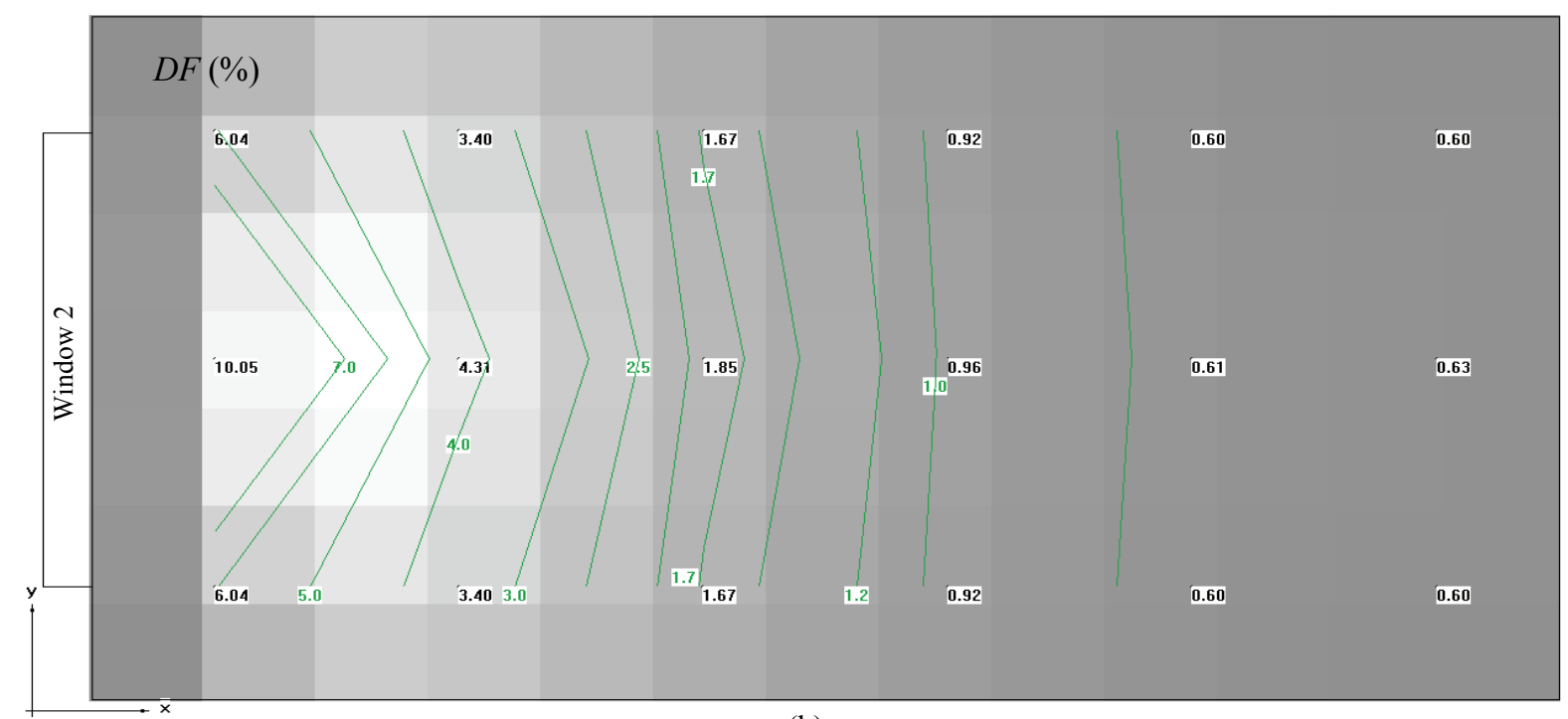

(b)

Room-floor dimensions: $3 \mathrm{~m} \times 6 \mathrm{~m}$, height $2.9 \mathrm{~m}$

(a) Window 1-width $1.5 \mathrm{~m}$, height $2.0 \mathrm{~m}$, sill height $0.9 \mathrm{~m}, D F_{\min }=0.66 \%, D F_{\max }=9.82 \%, D F_{\text {aver }}=2.37 \%, r=D F_{\min } / D F_{\max }=$ 0.07

(b) Window 2-width $2.0 \mathrm{~m}$, height $1.5 \mathrm{~m}$, sill height $0.9 \mathrm{~m}, D F_{\min }=0.60 \%, D F_{\max }=10.05 \%, D F_{\text {aver }}=2.49 \%, r=D F_{\min } / D F_{\max }$ $=0.06$

$D F(\%)$-daylight factor, $D F_{\min }-$ minimum value, $D F_{\max }-$ maximum value, $D F_{\text {aver }}$-average value

Fig. 1 Influence of a window position on daylighting within a room space: (a) horizontal window; (b) vertical window. 


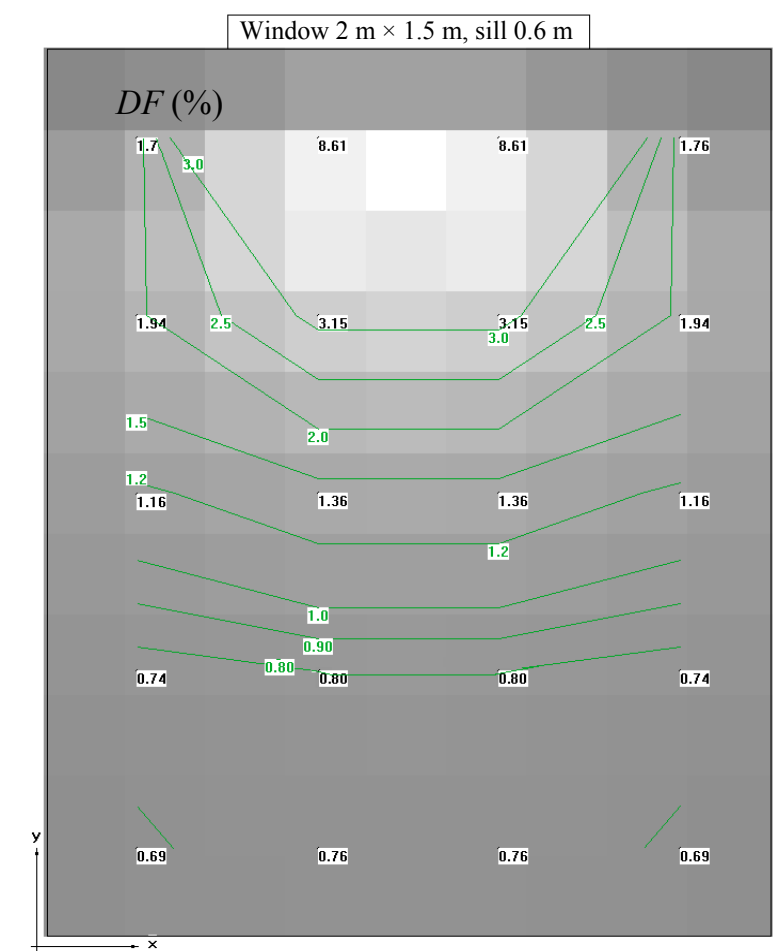

(a)

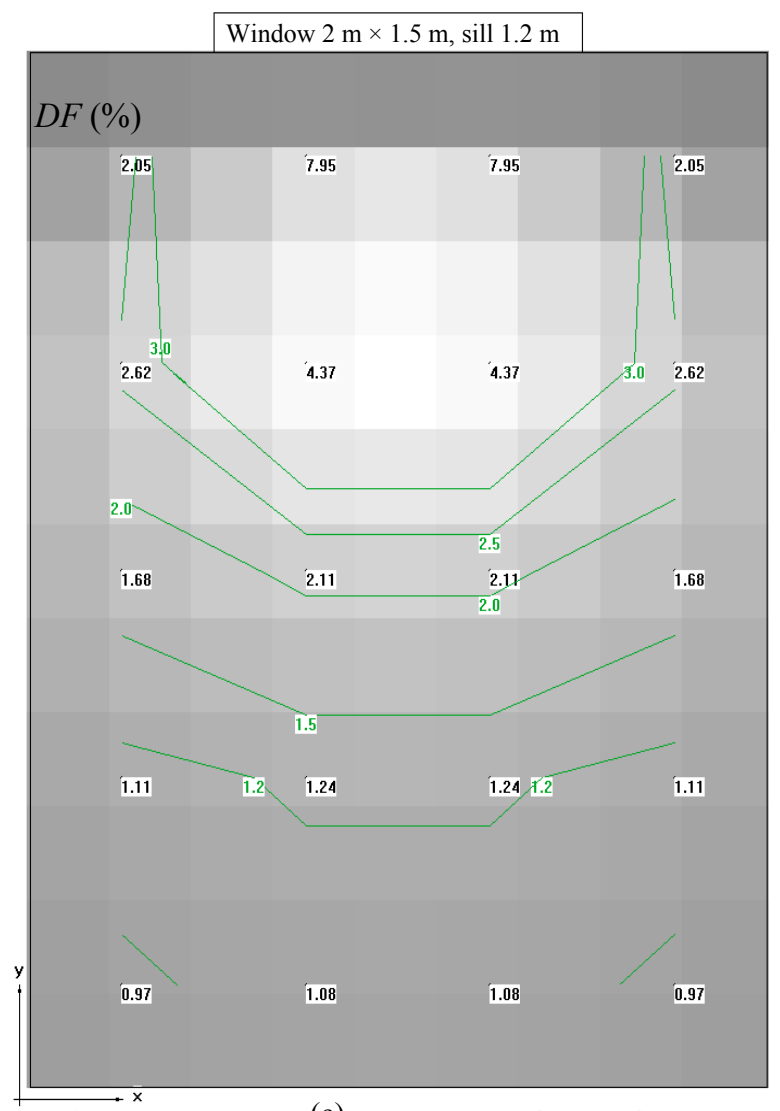

(c)

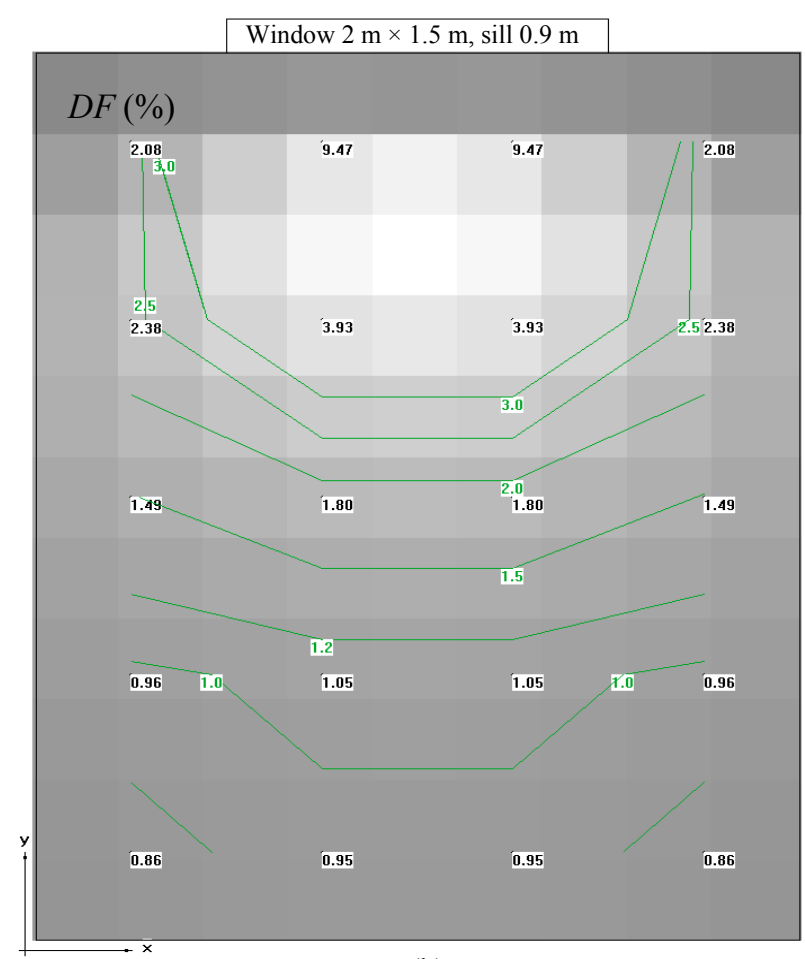

(b)

Room-floor area $4 \mathrm{~m} \times 5 \mathrm{~m}$, height $2.7 \mathrm{~m}$

(a) Window sill height $0.6 \mathrm{~m}$

$$
\begin{aligned}
& D F_{\min }=0.69 \% \\
& D F_{\max }=8.61 \% \\
& D F_{\text {aver }}=2.10 \% \\
& r=D F_{\min } / D F_{\text {max }}=0.08
\end{aligned}
$$

(b) Window sill height $0.9 \mathrm{~m}$

$$
\begin{aligned}
& D F_{\text {min }}=0.86 \% \\
& D F_{\text {max }}=9.47 \% \\
& D F_{\text {aver }}=2.50 \% \\
& r=D F_{\text {min }} / D F_{\text {max }}=0.09
\end{aligned}
$$

(c) Window sill height $1.2 \mathrm{~m}$

$$
\begin{aligned}
& D F_{\min }=0.97 \% \\
& D F_{\max }=7.95 \% \\
& D F_{\text {aver }}=2.52 \% \\
& r=D F_{\min } / D F_{\max }=0.12
\end{aligned}
$$

Fig. 2 Influence of a window sill height on daylighting within a room space: (a) window sill height $0.6 \mathrm{~m}$; (b) window sill height $0.9 \mathrm{~m}$; (c) window sill height $1.2 \mathrm{~m}$. 


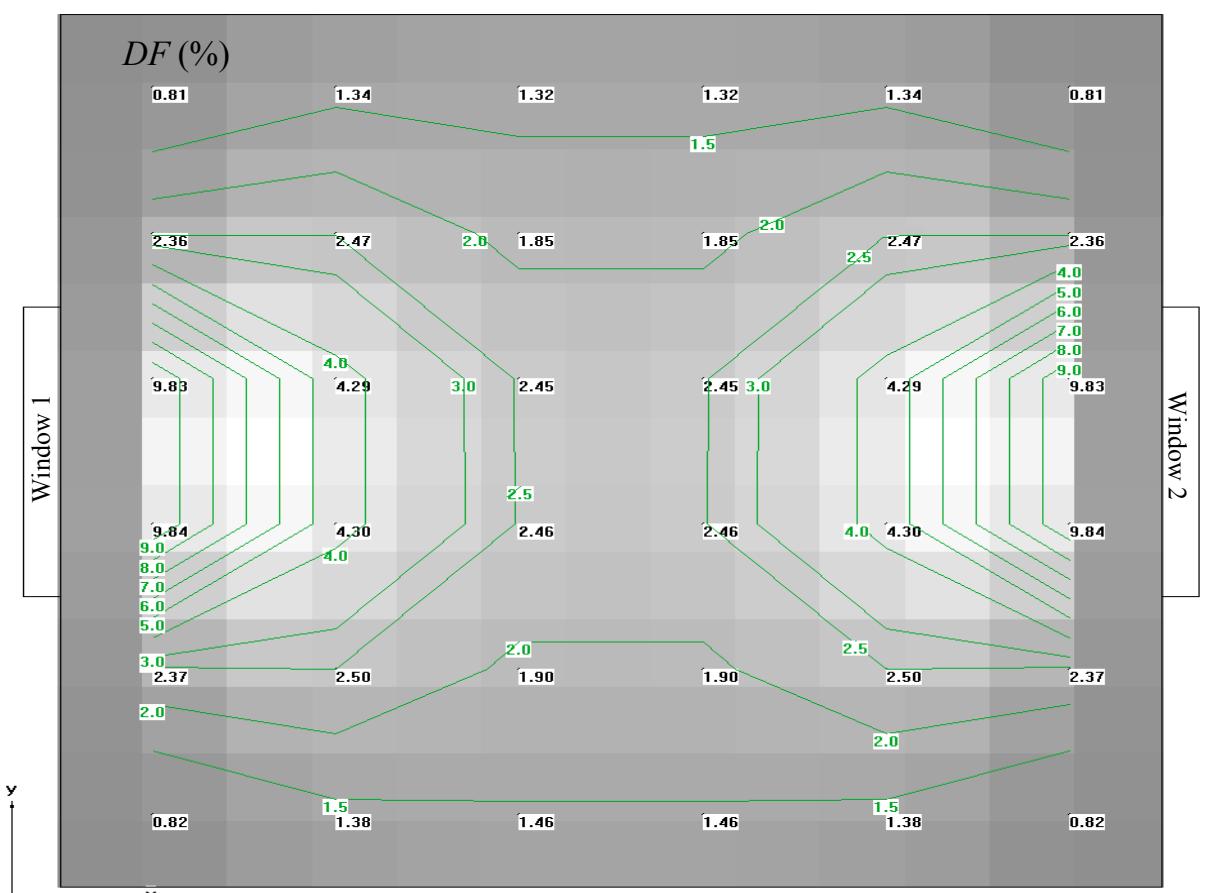

Dark corner

(a)

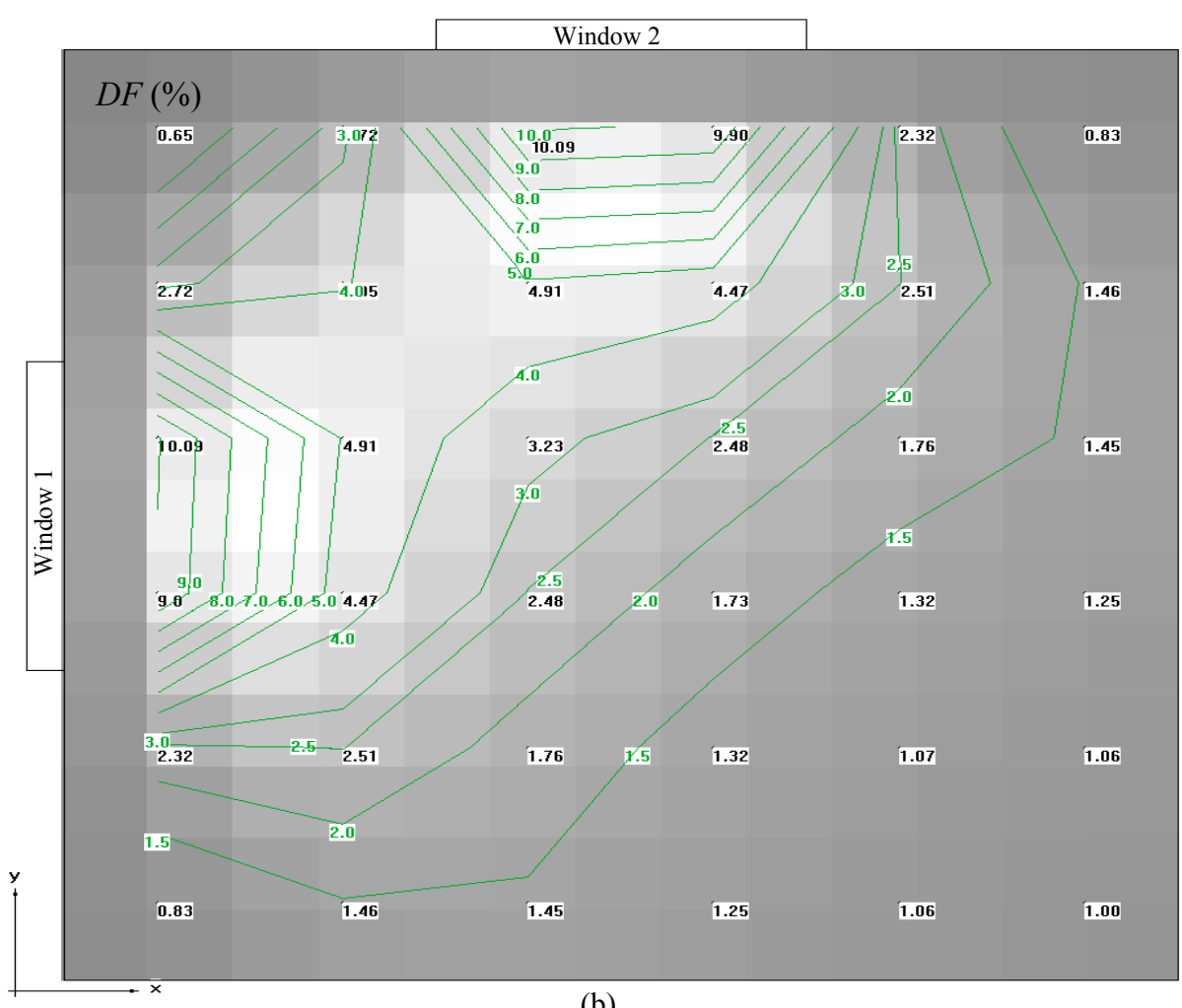

Room-floor area $6 \mathrm{~m} \times 6$

$\mathrm{m}$, height $2.7 \mathrm{~m}$

Two windows in parallel

walls

Window dimensions $2.0 \mathrm{~m}$

$\times 1.5 \mathrm{~m}$, window sills 0.9

$\mathrm{m}$

$D F_{\min }=0.81 \%$

$D F_{\max }=9.84 \%$

$D F_{\text {aver }}=3.01 \%$

$r=D F_{\min } / D F_{\max }=0.08$

Room-floor area $6 \mathrm{~m} \times 6$

$\mathrm{m}$, height $2.7 \mathrm{~m}$

Two windows in

perpendicular walls

Window dimensions $2.0 \mathrm{~m}$

$\times 1.5 \mathrm{~m}$, window sill $0.9 \mathrm{~m}$

$D F_{\min }=0.65 \%$

$D F_{\max }=10.09 \%$

$D F_{\text {aver }}=3.02 \%$

$r=D F_{\min } / D F_{\max }=0.06$

Fig. 3 Rooms with two separate windows in different walls: (a) two windows in parallel walls; (b) two windows in perpendicular walls. 

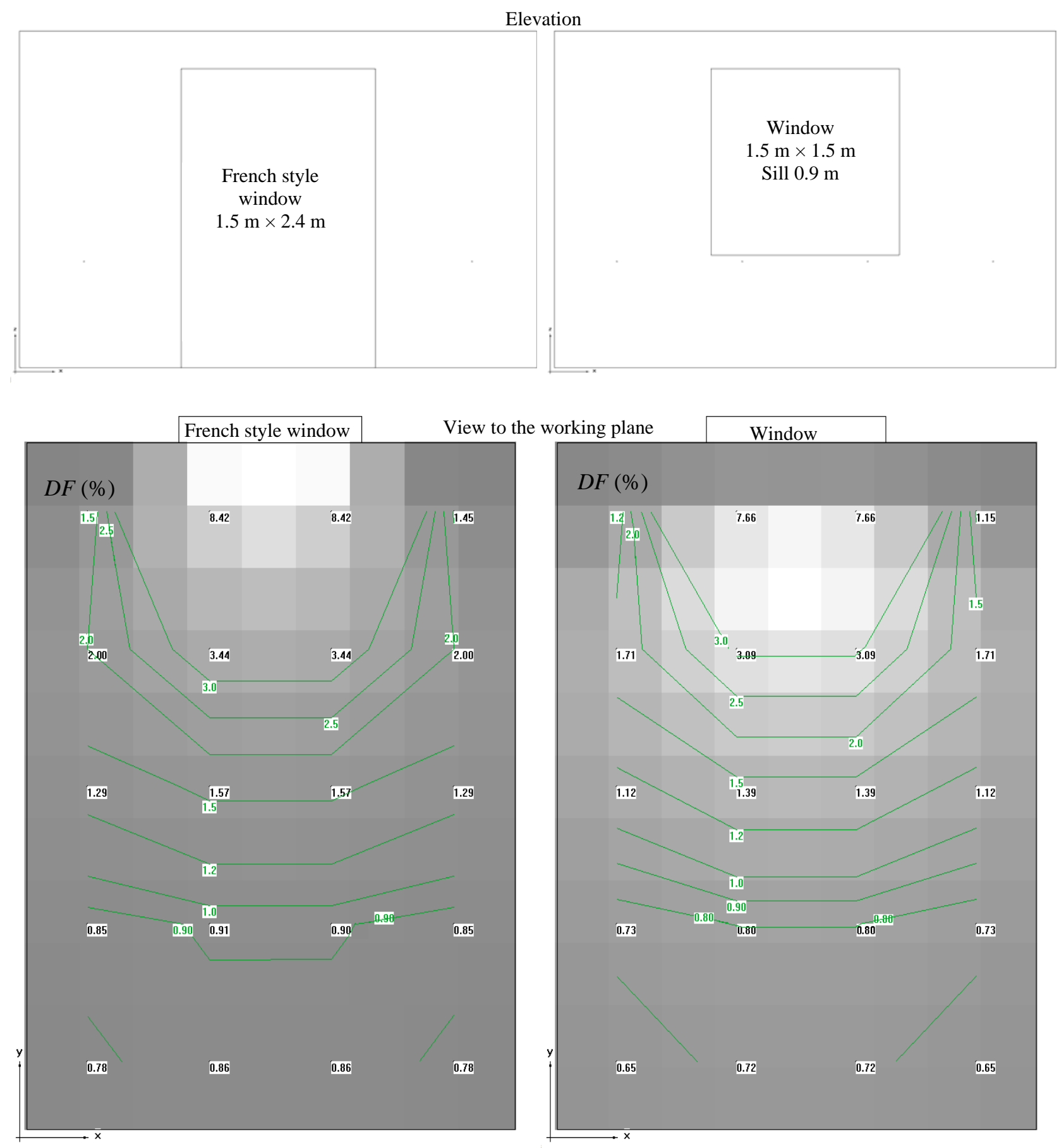

Room-floor area $4 \mathrm{~m} \times 5 \mathrm{~m}$, height $2.7 \mathrm{~m}$

$D F_{\min }=0.78 \%, D F_{\max }=8.42 \%, D F_{\text {aver }}=2.16 \%$,

$r=D F_{\min } / D F_{\max }=0.09$

Higher illumination level represented by daylight factor (\%) close to the window

Room-floor area $4 \mathrm{~m} \times 5 \mathrm{~m}$, height $2.7 \mathrm{~m}$

$D F_{\text {min }}=0.65 \%, D F_{\text {max }}=7.66 \%, D F_{\text {aver }}=1.90 \%$,

$r=D F_{\text {min }} / D F_{\text {max }}=0.085$

Higher illumination level is in the internal part of the room due to the window sill shading

(a)

(b)

Fig. 4 Daylighting by an ordinary window and a French style window: (a) room with a French style window; (b) room with an ordinary window. 


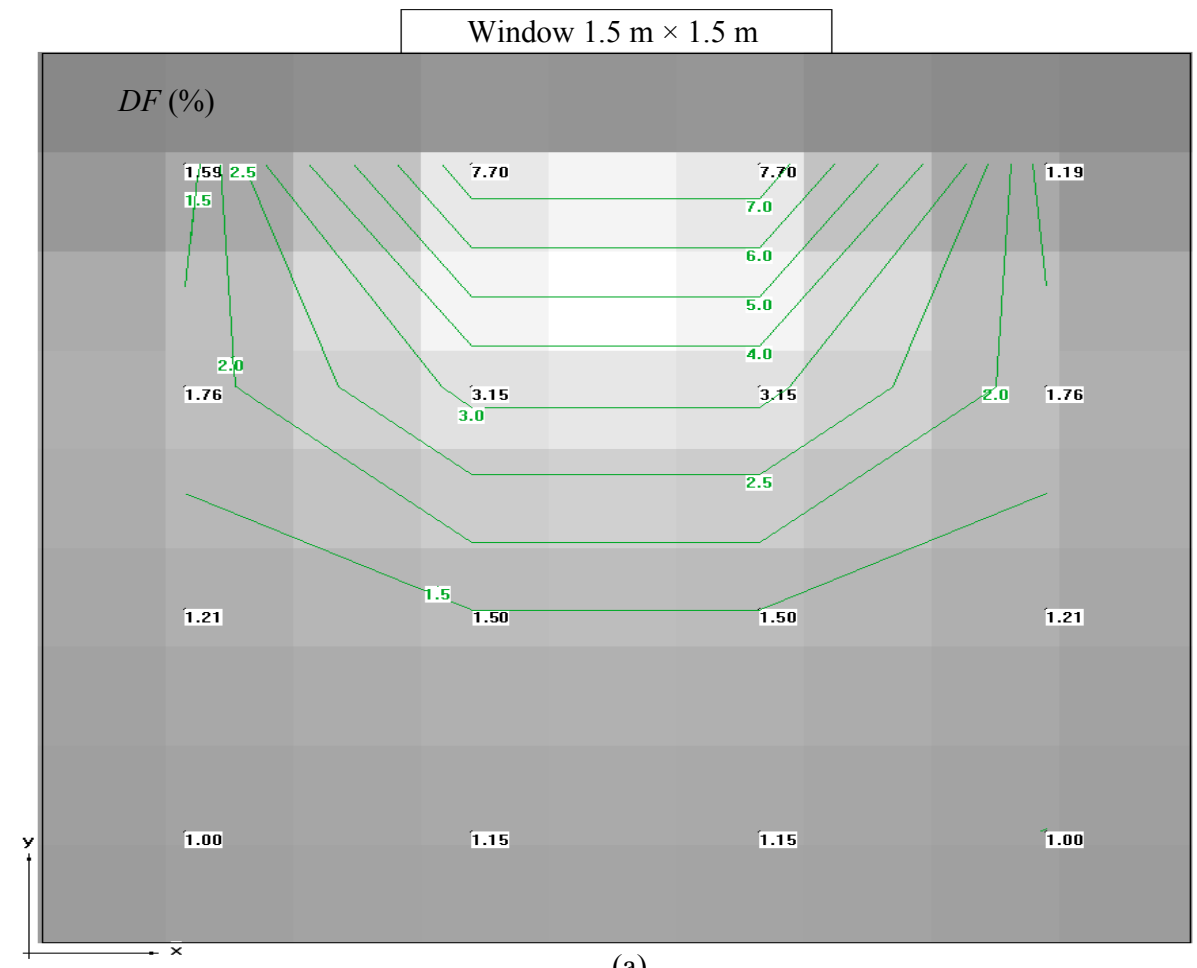

Room-floor area $4 \mathrm{~m} \times 4 \mathrm{~m}$, height $2.7 \mathrm{~m}$

Window dimensions

$1.5 \mathrm{~m} \times 1.5 \mathrm{~m}$, window sill $0.9 \mathrm{~m}$

$D F_{\min }=1.0 \%$

$D F_{\max }=7.70 \%$

$D F_{\text {aver }}=2.33 \%$

$r=D F_{\min } / D F_{\max }=0.12$

(a)

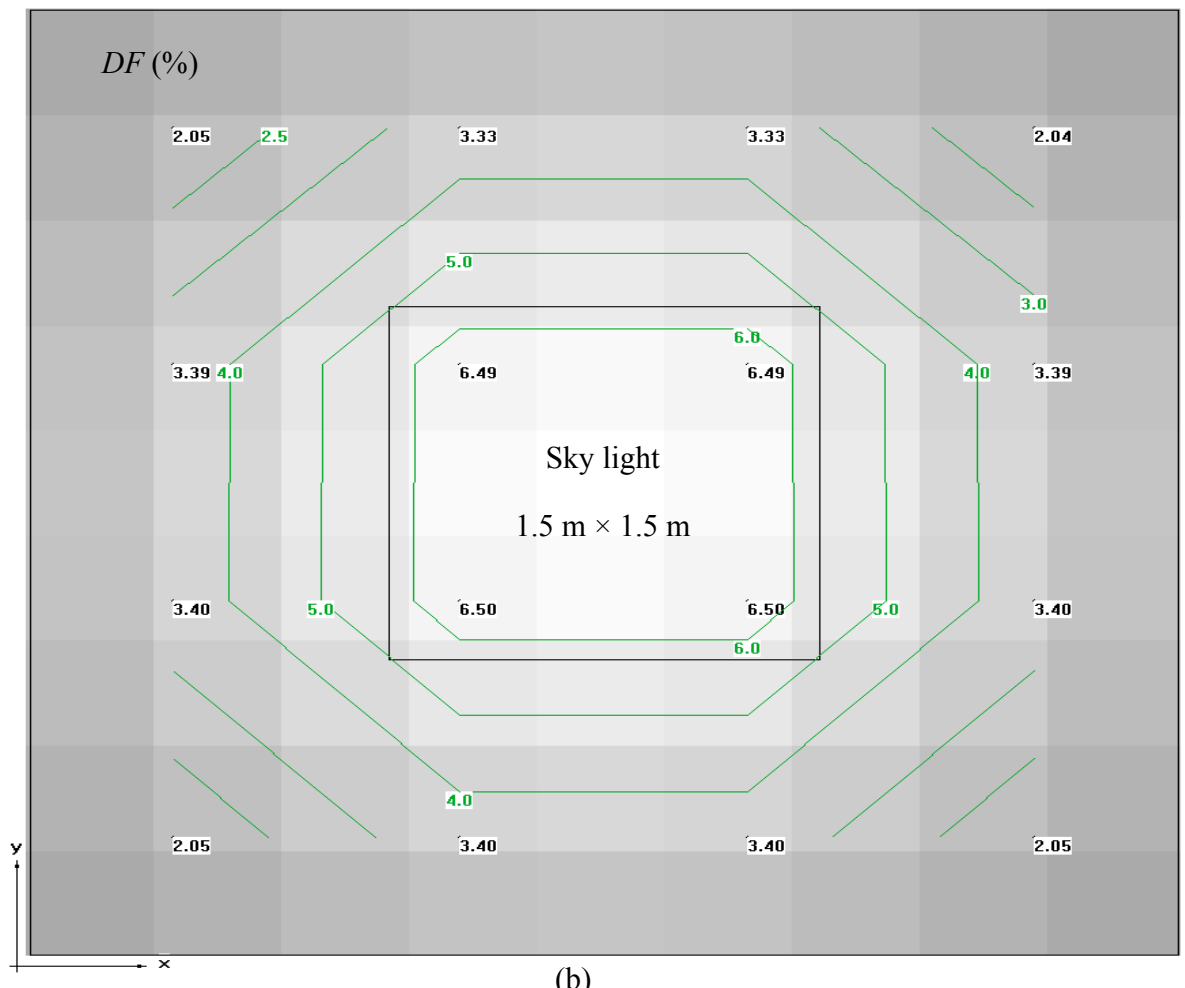

Room-floor area $4 \mathrm{~m} \times 4 \mathrm{~m}$, height $2.7 \mathrm{~m}$

Sky light dimensions

$1.5 \mathrm{~m} \times 1.5 \mathrm{~m}$

$D F_{\min }=2.04 \%$

$D F_{\text {max }}=6.50 \%$

$D F_{\text {aver }}=3.82 \%$

$r=D F_{\min } / D F_{\max }=0.31$

(b)

Fig. 5 Influence of side window and skylight on daylighting within: (a) room space with window; (b) room with sky light. 


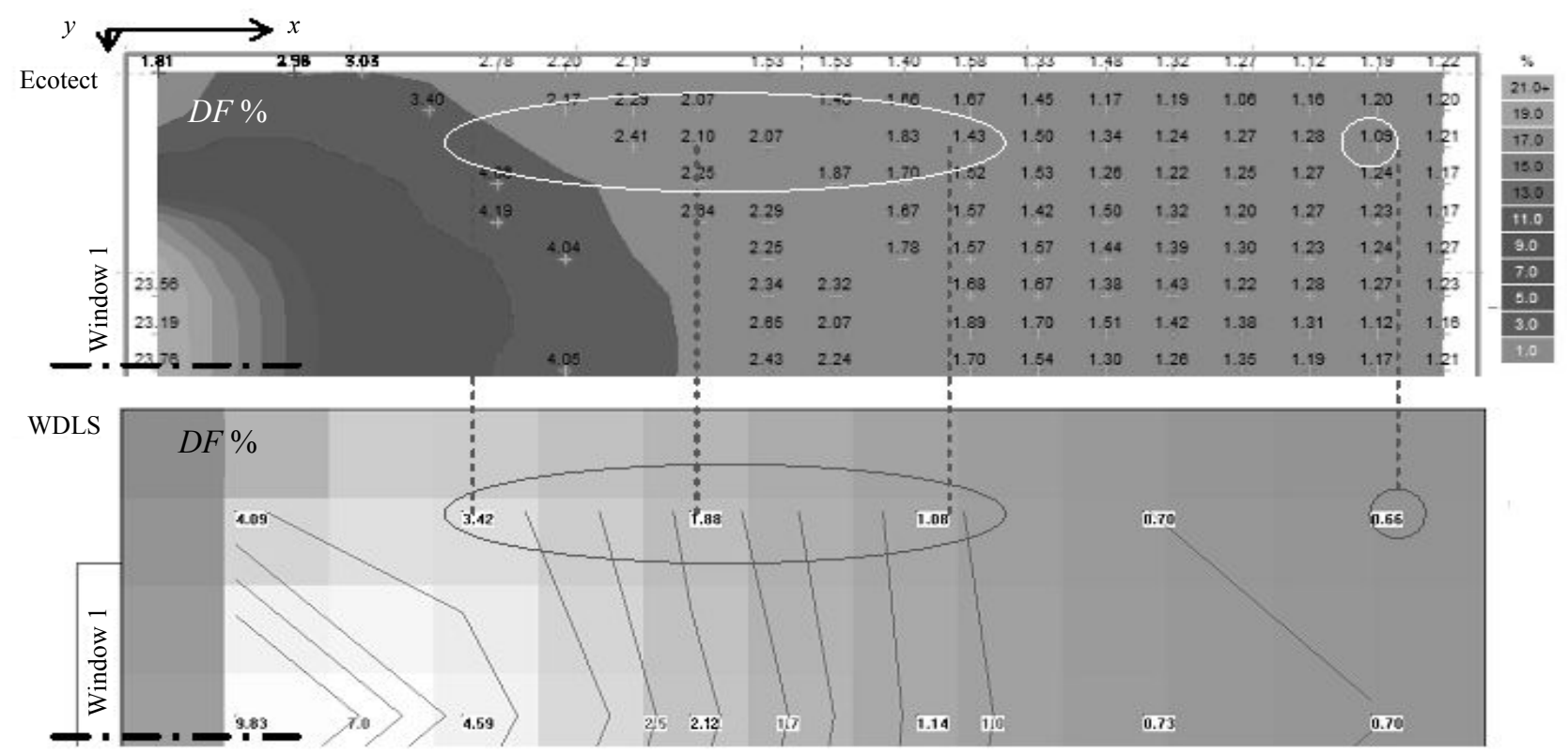

Fig. 6 Results of comparison-segment of the room with window 1 from Fig. 1a: Ecotect and WDLS software.

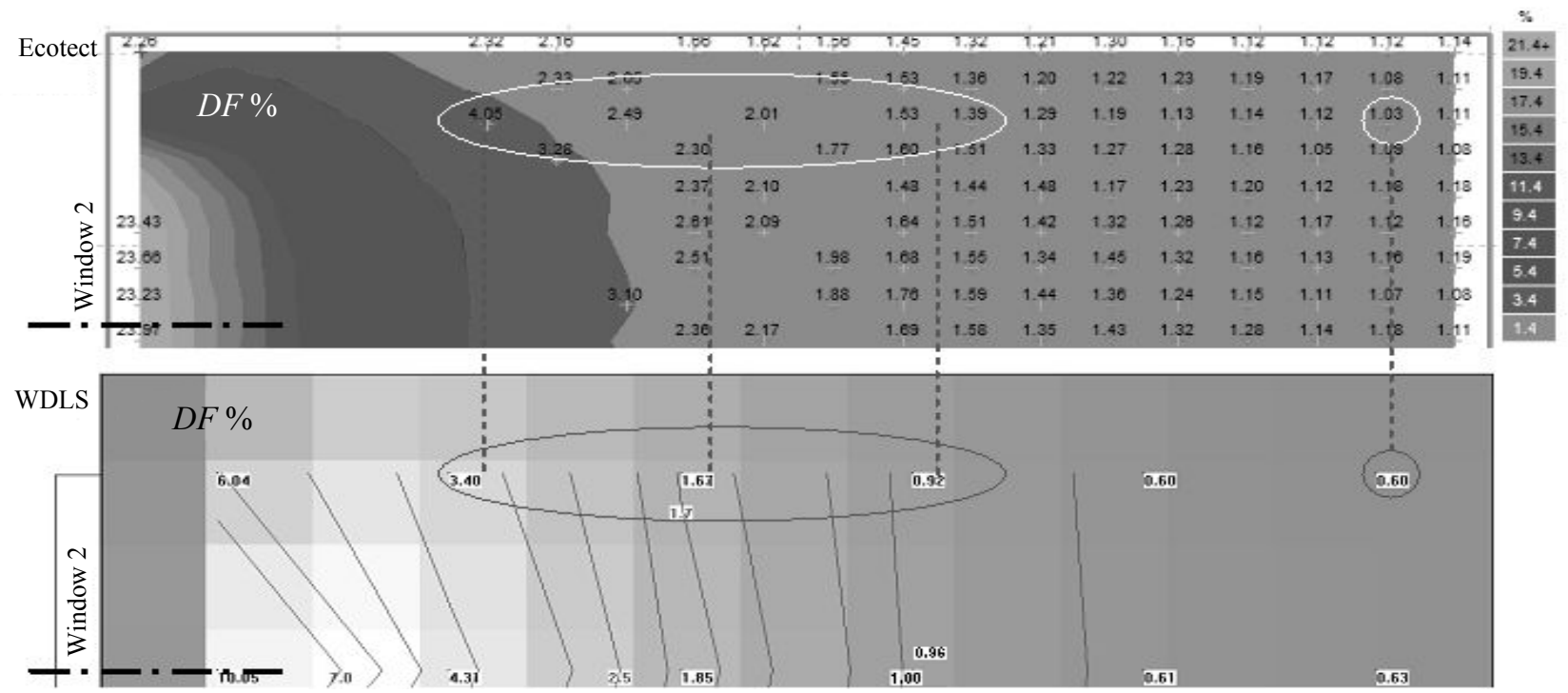

Fig. 7 Results of comparison-segment of the room with window 2 from Fig. 1b: Ecotect and WDLS software.

Table 1 Results from simulations.

\begin{tabular}{|c|c|c|c|c|}
\hline Control point $x / y$ & $1.5 / 0.5$ & $2.5 / 0.5$ & $3.5 / 0.5$ & $5.5 / 0.5$ \\
\hline \multicolumn{5}{|c|}{ Window 1 -width $1.5 \mathrm{~m}$, height $2.0 \mathrm{~m}$, sill height $0.9 \mathrm{~m}$} \\
\hline Ecotect & $3.74 \%$ & $2.10 \%$ & $1.63 \%$ & $1.09 \%$ \\
\hline WDLS & $3.42 \%$ & $1.88 \%$ & $1.08 \%$ & $0.66 \%$ \\
\hline Difference & $0.32 \%$ & $0.22 \%$ & $0.55 \%$ & $0.43 \%$ \\
\hline \multicolumn{5}{|c|}{ Window 2 -width $2.0 \mathrm{~m}$, height $1.5 \mathrm{~m}$, sill height $0.9 \mathrm{~m}$} \\
\hline Ecotect & $4.05 \%$ & $2.25 \%$ & $1.48 \%$ & $1.03 \%$ \\
\hline WDLS & $3.40 \%$ & $1.67 \%$ & $0.92 \%$ & $0.60 \%$ \\
\hline Difference & $0.65 \%$ & $0.58 \%$ & $0.56 \%$ & $0.43 \%$ \\
\hline
\end{tabular}

Control point $x / y$-positioning of the control point in direction of axis $x / y$ (Figs. 6 and 7). 


\section{Conclusions}

The paper presents results of a study where daylight computer simulations have been carried out for evaluating the window influence on daylighting of a room space. In the study, example window design of rooms in a residential building has been utilised as a case study.

In summary, it can be concluded that the side windows are recommended to be higher to allow daylight transmittance into the room depth. On the other hand, windows with very low sills increase solar gains while very high window sills limit direct view to streets.

When the vertical window is compared with the roof light of the same dimension, it is clear that the side light offers visual contact to exterior space but the skylight offers better daylight illuminance and uniformity.

Windows and sky lights should be designed in relation with design considerations of solar gains in order for optimized daylighting in room spaces. Modern buildings are equipped and integrated with control systems of daylight and artificial lighting, and their maintenance as well as the solar shading systems incorporated is controlled by windows and other glazing areas. Today, it is possible to design zones in buildings with respect to the facilities such as building operation and integrated technology and, in particular, indoor visual activities.

The holistic approach to window design for optimal daylighting without glare and overheating requires consideration of many design aspects influenced by professional services such as electric lighting, heating, ventilation, cooling and others. Daylighting is important for indoor comfort as well as energy savings in buildings.

\section{Acknowledgments}

The research presented in the article was supported by the project TE02000077, Smart Regions-Buildings and Settlements Information Modelling, Technology and Infrastructure for Sustainable Development.

\section{References}

[1] Baker, N., and Steemers, K. 2001. Daylight Design of Buildings - A Handbook for Architects and Engineers. London: James and James.

[2] Tregenza, P., and Wilson, M. 2011. Daylighting: Architecture and Lighting Design. New York: Routledge.

[3] Fontoynont, M. 1999. Daylight Performance of Buildings. London: James and James.

[4] IEA (International Energy Agency), and SHC (Solar Heating and Cooling Program). 2000. A Source Book on Daylighting Systems and Components. Final report of IEA SHC, energy conservation in buildings and community systems, Task 21. Accessed September 5, 2014. http://eetd.lbl.gov/btp/iea21/1 eapuba.html.

[5] IESNA (Illuminating Engineering Society of North America). 2000. The IESNA Lighting Handbook. Reference and Application. 9th ed.. New York: The IESNA.

[6] Carmody, J., Selkowitz, S., and Heschong, L. 1996. Residential Windows-A Guide to New Technologies and Energy Performance. New York: W.W. Norton \& Company.

[7] Robbins, C. L. 1986. Daylighting: Design and Analysis. New York: Van Nostrand Reinhold Company.

[8] Astra MS Software. 2014. "WDLS Daylight Simulation Software." Astra MS Software. Accessed September 15, 2014. http://www.astrasw.cz/cs/content/wdls.

[9] Petinelli, G., and Reinhart, C. 2006. "Advanced Daylight Simulations Using Ecotect, Radiance, Daysim.” Accessed September 15, 2014. http://web.mit.edu/Sustainable DesignLab/projects/TeachingResources/GettingStartedwi thEcotectRadianceDaysim.pdf.

[10] LBNL (Lawrence Berkeley National Lab). 2014. "Radiance Lighting Simulation Software." Accessed September 15, 2014. http://www.radiance-online.org/.

[11] DesignBuilder. 2014. "Advanced Building Energy Simulation and Fastest Modelling Technology Software." DesignBuilder. Accessed September 15, 2014. http://www.designbuilder.co.uk/content/view/114/181/. 